\title{
Review of An African Background to the Old Testament By Isaac Boaheng
}

\author{
Vusimuzi Goodman Nkuna' \\ 1 South African Theological Seminary, Sandton, South Africa.
}

\section{BIBLIOGRAPHICAL INFORMATION}

Author: Isaac Boaheng

ISBN 978-9988-3-2359-2

DOI:10.38159/npub.eb2021901

Published: 23rd September, 2021.

Publication URL - https://noyam.org/eb2021901/

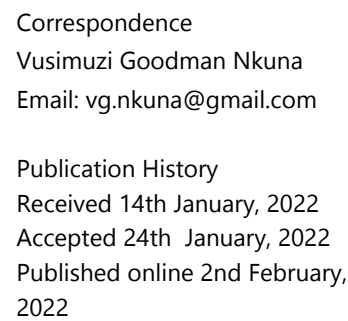

\section{INTRODUCTION}

This paper presents a critical review of the book titled An African Background to the Old Testament written by Rev. Dr. Isaac Boaheng. The purpose of this review is to assess how this book has achieved its objective of enhancing African readers' contextual reading of the Old Testament(OT). From my perspective as a graduate student in Practical Theology, I am of the opinion that the book has achieved this purpose. Therefore, this review serves to sustain this assertion. The review starts by presenting the book's overview commencing from the Foreword and ending with Chapter 7. I then conclude the review with a brief evaluation of the extent to which the book has achieved its stated and implied goal(s) followed by some recommendations.

\section{OVERVIEW OF ITS CONTENT}

\section{Foreword, Preface and Introduction}

Written by Dr. Joel Mokhoathi, Senior Lecturer in Religious Studies from the University of Free State, South Africa the foreword describes this book as a resource that enables African readers to use the OT to interpret their cultural context and ideas. ${ }^{1}$ In its preface, Boaheng clarifies that the book is written to help African Bible students to access the right background information needed for informed theological reflection within the African setting. ${ }^{2}$ The preface also clarifies that the book's main audience are lay-preachers, academics and specialists in the area of biblical and religious studies with special reference to OT. ${ }^{3}$

In its introductory chapter, the book presents its purpose, methodology and content overview. The author specifies that he wrote it to "showcase the numerous connections that the African society has with the biblical word to facilitate a better understanding of God's word within their own setting." ${ }^{\text {The chapter }}$ also states that as the book's main readership entails both undergraduate and postgraduate students, it also includes a set of questions at the end of each chapter for reflection and revision.

\footnotetext{
Page vii.

Page xi.

Page ix.

Page xiii.
} 


\section{Chapter 1 - Inspiration, Canonization and Transmission}

Boaheng acknowledges that he uses this chapter to offer elementary knowledge to the study of OT, ${ }^{5}$ focusing on its inspiration, canonization and transmission. With this chapter, he clarifies the doctrine of inspiration, canonization principles, divisions of OT, the Apocrypha, Judaism's Hebrew Bible, the human factor in Bible authorship and the role of oral tradition. He also shows the connection between Jewish oral tradition and the African oral tradition. He also enlightens the readers on the various materials that were used in developing biblical manuscripts and how some of them relate to the traditional African practices, e.g. inscriptions on rocks. The chapter also discusses biblical languages and points out that the Hebrew language is part of the Semitic family of languages that are also spoken in parts of North Africa and East Africa. ${ }^{6}$

\section{Chapter 2 - Geographical Background}

This chapter presents the general geographical milieu of the Ancient Near East, inclusive of specific geographical settings of ancient Israel, and their linkage to that of Africa. Of significance to the African readers, the book covers the noticeable presence of ancient Egypt and to some extent Cush in the OT text. Regarding Egypt, the book covers its ancient religion and how its gods were challenged by the God of Israel through plagues recorded in the book of Exodus. In addition, the chapter also touches on the demographic aspects of this geography by highlighting that amongst the inhabitants of the area were Africans who feature in the OT text, namely Nimrod (Genesis 10), Manasseh and Ephraim (Genesis 10), Cushan Rishathiam (Judges 3), and Abishag (1 Kings 1, 2). ${ }^{7}$

\section{Chapter 3 - Historico-Political Background}

The chapter discusses some of the major empires that featured during ancient Israel, viz. the Sumerians, Akkadian, Assyrian and Persian empires. The book states that Sumerian Empire had inhabited southern Mesopotamia during the fourth to the second millennia BCE. ${ }^{8}$ It further discusses that the Sumerians were polytheistic, had an established political system, and used to make human sacrifices for their kings like some African tribes do. ${ }^{9}$ One of the most prominent and powerful empires mentioned in the book is the Babylonian Empire which reigned in Mesopotamia from 1900 to $500 \mathrm{BCE}^{10}$. The book states that this empire actually became the world's superpower after conquering the Assyria capital in 612 BCE. ${ }^{11}$ Another notable empire is the Assyrian Empire which this book says was known for its fearsome military prowess and use of deadly chariots and iron weapons in war. ${ }^{12}$ Lastly the book states that the Persian Empire rose into power under the rulership of Cyrus who used religious and cultural tolerance to maintain order. ${ }^{13}$ Of significance to the African reader, the book states that this empire's territory included Nubia in northeastern Africa. ${ }^{14}$

\section{Chapter 4 - Social Background}

In this chapter, Boaheng presents the relationship between the social background of ancient Israel and that of the traditional Africans. ${ }^{15}$ Among other aspects, he describes the nomadic life of ancient Israel from the era of Abraham and affirms that such patterns were prevalent among African nomads. He further examines family and community life and notes that in ancient Israel family members were united by religious observances and

\footnotetext{
Page 21 .

Page 15.

Page 26.

Page 54

Page 54-58.

Page 59.

Page 61.

Page 64.

Page 65.

Page 61.

Page 69.
} 
economic interdependence. ${ }^{16} \mathrm{He}$ argues that, similar to ancient Israel, "traditional Africans live in nuclear households, often with their relatives in clusters of houses around a common yard." ${ }^{17}$ Likewise, the chapter also covers aspects of marriage, the communal worldview of wealth and interdependence.

In his comparison of ancient Israel and traditional African societies' similar traditions, Boaheng is not ignorant of their unique discrepancies. This is illustrated in his discussion of the practice of circumcision where he indicates that under Mosaic Law newborn Hebrew males were circumcised during the eighth day after birth in observance of their covenant with Yahweh, while in the African context the motif is different. ${ }^{18}$ For instance, he notes from literature that among the Xhosa people of Southern Africa, male circumcision is practiced as a principal rite of initiation, ${ }^{19}$ as is the case with many other traditional African societies.

\section{Chapter 5 - Economic Background}

The chapter draws parallels between the economy of ancient Israel and the traditional African economy. ${ }^{20}$ The book alludes that in both contexts, land is evidently treated as a means of living and has predominantly been used for farming. ${ }^{21}$ The rest of the chapter discusses a number of resources which formed part and parcel of and/or enablers in the economy of ancient Israel such as water sources, transport system and metrology. While the book does not provide enough comparative information on these aspects, Boaheng counsels that knowing them will serve as a hermeneutical key for OT students. ${ }^{22}$

\section{Chapter 6 - Religious Background}

This chapter covers the ancient Jewish religious tradition with specific reference to priesthood and temple worship which according to Boaheng might or could not have parallels in the African community. ${ }^{23}$ The chapter also includes a discussion on religious observances like the Passover as well as the role of the synagogue. Boaheng concludes the chapter by highlighting the significance of OT blood sacrifices in the development of the "doctrine of Jesus' once-for-all sacrifice." ${ }^{24}$ The book argues that for many Christian traditions, Jesus Christ's crucifixion has replaced all forms of animal sacrifices which were offered to God in the OT and as practiced in some African Traditional Religions.

\section{Chapter 7 - Intertestamental Background}

The chapter offers an exposition of the political, religious and socio-economic contexts of the intertestamental period. ${ }^{25}$ Boaheng states that an understanding of this setting is important not only to OT scholarship but also contextualizes Christianity's emergence from Judaism. In the political context, he highlights the repressive conditions which confronted ancient Israel under the imperial rule of Alexander the Great, Ptolemy and Antiochus III, respectively. The chapter also cites how deliberate attempts by Antiochus, in alliance with the Syrians failed to exterminate Judaism due to resistance from the Maccabees. ${ }^{26}$ In addition to discussing how the Maccabees contributed to the preservation of Judaism, the chapter brings to light the Judaism sects that were prevalent in Israel during that period. Probably, a point of significance to the African context is that Alexander founded the city of Alexandria in Egypt. ${ }^{27}$ Ferdinand Deist whose work features in this book latently reveals the importance of this move by Alexander. He states that this city became a hub

\footnotetext{
16 Page 74.

17 Page 76.

18 Page 85.

19 Page 84.

20 Page 86.

21 Page 87-88.

22 Page 97.

23 Page 99.

24 Page 110.

25 Page 112.

26 Page 122-124.

27 Page 114.
} 
of Hellenistic culture where a university which later became a centre of learning during the Christianity era was built. ${ }^{28}$

\section{EVALUATION}

The outcome of this review suggests that this book has achieved all its objectives. The evidence of enabling "African readers' contextual reading of the Old Testament" was revealed by its instant citation by African scholars, such as Vusimuzi Nkuna who did so within three months of its publication. ${ }^{29}$ In the same article, Nkuna also inadvertently affirmed the book's intent to enable "African readers to use the OT to interpret their cultural context and ideas" by using some of its content in analyzing the state of religious pluralism in South Africa. This anecdotal evidence suggests that the book would equip many other African Bible students to access the right background information needed for informed theological reflection within the African setting. The book also clearly achieved its goal to "showcase the numerous connections that African society has with the biblical word." These connections relate to historical, cultural, political, geographical and religious contexts, just to highlight a few.

While Boaheng modestly limits the book's audience to students and lecturers in the field of Theology, its content can also be useful in other disciplines in the humanities. For instance, its content on socio-cultural aspects are relevant to Anthropology, Sociology and Social Psychology. The geographical background may be useful to Geography in the areas of climatology and settlement geography. It may also invoke an inquiry in the field of Archeology to investigate some of the details about the context of that area. This implies that, while it was necessary for the author to carefully demarcate its audience, any careful reader from these fields may find some of this book's content very relevant to their respective fields.

The book's African perspective is as inclusive as possible, regardless of the author's West African heritage. While it could not be possible to use every available example of the African context to illustrate aspects covered in the book, Boaheng has demonstrated a substantial attempt to be as inclusive as possible. This implies that the book has achieved its African specificity as mentioned in the title and its implied goal(s). Likewise, its content also concurs with the works of other prominent African scholars in the field such as Tuesday Adamo who revealed that Africa and Africans are mentioned more than any other foreign nations in the OT. ${ }^{30}$ Lastly, the idea of writing this book with little OT jargon makes its content accessible to non-specialists as well, a challenge that OT scholars such as Aloo Mojola who wrote on a related topic, notes could affect the vast majority of the OT readers. ${ }^{31}$

\section{RECOMMENDATION}

The above evaluation explicitly reveals my recommendation of this book to a wider audience than initially anticipated. Both undergraduate and graduate students will undoubtedly benefit from reading this book to get a holistic perspective of the connection between the African context and that of ancient Israel. It could also equip ministers of the gospel to use OT text hermeneutically in their sermons. The use of this book for tuition in homiletics and pastoral care should be considered as some of its content could be used as case studies to enrich practical lessons in these two areas of theology.

28 Ferdinand E. Deist, From Eden to Rome: The Narrative Literature of the Bible: Story, Composition and Author's Point of View (Pretoria: Van Schaik Publishers, 2004), 132.

29 Vusimuzi G. Nkuna, "Comparative Analysis of the State of Religious Pluralism between Intertestamental Palestine and PostApartheid South Africa," E-Journal of Humanities, Arts and Social Sciences 2, no.12 (2021), 225-226.

30 David T. Adamo, "The Historical Development of the Old Testament Interpretation in Africa," The Historical Development OTE 16, no.1 (2003), 23.

31 Aloo O. Mojola, "The Old Testament or Hebrew Bible in Africa: Challenges and prospects for interpretation and translation," Verbum et Ecclesia 35, no.3 (2014), 1. 


\title{
REFERENCES
}

Adamo, David T., "The Historical Development of the Old Testament Interpretation in Africa," The Historical Development OTE 16, no.1 (2003): 9-33.

Deist, Ferdinand E., From Eden to Rome: The Narrative Literature of the Bible: Story, Composition and Author's Point of View (Pretoria: Van Schaik Publishers, 2004).

Mojola, Aloo O., "The Old Testament or Hebrew Bible in Africa: Challenges and prospects for interpretation and translation," Verbum et Ecclesia 35, no.3 (2014). https://doi.org/10.4102/ve.v35i3.1307

Nkuna Vusimuzi G., "Comparative Analysis of the State of Religious Pluralism between Intertestamental Palestine and Post-Apartheid South Africa," E-Journal of Humanities, Arts and Social Sciences 2, no.12 (2021): 224-233. https://doi.org/10.38159/ehass.20212123

\begin{abstract}
ABOUT AUTHOR
Vusimuzi Nkuna received his MTh with distinction from North-West University, South Africa. He also holds an MBA from the University of South Africa and a BA Social Work from the University of Fort Hare, South Africa. He is at the foundational stage of his studies towards a PhD in Theology at the South African Theological Seminary. He has been a mentor at the Faculty of Theology and Religion at the University of Pretoria, South Africa since 2020. His research interests include pastoral care, the occult in Africa and freedom of religion.
\end{abstract}

